\title{
PERFORMANCE OF INVESTMENT MANAGEMENT: A STUDY ON SOCIAL ISLAMI BANK LIMITED (SIBL)
}

\author{
Sanzida Tasnim \\ Department of Management \\ Faculty of Business Studies \\ University of Dhaka, Bangladesh \\ E-mail: sanzida122@gmail.com \\ Ariful Islam \\ Lecturer \\ Department of Economics \\ Faculty of Social Science \\ Rabindra University, Bangladesh (RUB) \\ Shahzadpur, Sirajganj, Bangladesh \\ E-mail: arif_islam@econdu.ac.bd
}

\begin{abstract}
This study attempts to understand the level of efficiency of investment management of social Islami bank limited (SIBL). In this regards, different aspects (i.e., amount, ratio, profit and growth) of deposit, investment, investment modes and procedures are scrutinized thoroughly. To conduct the study, secondary data sources have been primarily used. Some information was also collected from officials over the phone. The study was based on five consecutive years i.e., 2015 to 2019.The major findings are that the ratio of investment deposit also remains as high as $90 \%$. The bank invests more in Murabaha, Bai-Muazzal, HPSM and Quard. The ratio of classified investment to total investment increased $8.20 \%$ till 2017 and decrease to $6.63 \%$ up to 2019 whereas the ratio of unclassified investment decrease to $89.09 \%$ till 2017 and increase to 91.71\% up to 2019. There has an increase of sub-standard and doubtful investments till 2017 and a decrease up to 2019. But in case of bad or loss investment, an upward trend has been observed till 2018 and had a negligible decrease in 2019. The last part of the analysis shows that the overall profit growth of investment fluctuated over years but remains positive i.e., 11.39\%. In conclusion, the bank is moderately efficient in investment management.
\end{abstract}

Keywords: Islamic Banking; Investment; management, Profitability and Efficiency.

JEL Classification Codes: G11, G24, O16.

\section{INTRODUCTION}

To understand the importance of the banking business and its contribution to an economy, it is important to learn how the banking system works and how it executes the cost-benefit analysis. Social Islami Bank Limited (SIBL) comprised of SIBL Securities Ltd, SIBL Investment Ltd, SIBL Foundation Hospital, a second-generation commercial bank, is a leading value-added bank 
based on Shariah' Principles. It offers the most up to date banking services. It has an efficient credit and risk management department which allows it a competitive and effective serviceoriented technology-driven profit-earning Bank. SIBL was able to reduce the classified loan and unclassified loan by $6.63 \%$ and $20.53 \%$ respectively in 2019 with a focus to improve asset quality, the sustainability of profit growth, recovering classified and written-off loans (Social Islami Bank Limited [SIBL], 2020). Capital accumulation and loan disbursement and its recovery cover a major part of the banking business. In this study, the performance of investment management is attempted to explain meticulously. It is also endeavored to elucidate the independence of loan, risk and profitability thoroughly as loan, credit and income the three concerning parts for a bank.

This study will be helpful to understand the performance of investment management of Social Islami Bank (SIBL). To have a grasp of the topic, the investment management section of several annual reports of SIBL is analyzed along with the overall performance of the bank. It is of vibrant importance of cash flow, risk and profitability. If credit can be properly managed, it will help to the assessment of risk and collection of debts which in turn increases the operating resources of a bank. Besides, it can be said that the bank as an intermediary institution between economic development and investment equilibrates sustainable and socially conducive investment management. Therefore, effective investment management should be highly prioritized.

\section{Objectives of the Study}

- The primary objective of this study is to evaluate the performance of investment management of Social Islami Bank Limited.

- The secondary objectives of this report are to find out the basic criteria of investment and investment management practice of a bank, analyze investment management practices of Social Islami Bank Limited (SIBL), explore the findings and problems faced by Social Islami Bank Limited (SIBL) in investment management and suggest some recommendations of the bank in this regard.

\section{LITERATURE REVIEW}

The viability and sustainability of banks depend on the degree of efficiency in loan management. Loan management consequently affects various business goals and achievements of banks. The performance of investment management depends on investment application processing, screening, granting, monitoring and control efforts of investments. It is an important mechanism to reduce the frequency and intensity of loss that a bank might experience.

Rosenberg and Gleit (1994) showed their perspectives about some theories and models on how to assist decision making in the area of consumer and commercial credit. They analyzed discriminant analysis, decision trees, and expert systems for static decisions, and dynamic programming, linear programming, and Markov chains for dynamic decision models using legal considerations, sources of data, and statistical validation of the methodology.

According to findings of Ahmad and Hassan (2007), an interbank Islamic money market is absent, following the same policy and guidelines for Islamic and conventional banking by the Bangladesh Bank, presence of a discriminatory legal reserve requirement for Islamic and conventional banking, the prevalence of a restrictive environment in the capital market, and the lack of legal support and protection of Bangladesh Bank to avoid the associated risks of Islamic banks. 
Sufian and Habibullah (2009) suggest that bank-specific characteristics, in particular loan intensity, credit risk, and cost have positive and significant impacts on bank performance, while non-interest income exhibits a negative relationship with bank profitability.

Akber and Dey (2020) exhibited that conventional commercial banks performs better than Islamic banks in terms of quality of management and asset quality. Furthermore, Studies show that Islamic banking cannot utilize its full efficiency and potentialities under the framework of conventional banking because of efficiency-blunt operations of the conventional banking system, Sarker (1999a). He further said that the performance of Islamic banks could be better if micro, small and medium enterprises (MSMEs), research and development and pro-poor schemes get priority in investment decisions of the banks (Sarker, 2010b).

Comparing the profitability ratio to the default rate, cost of per loan assets and capital adequacy ratio with banks' financial performance, Poudel (2012) showed that there exists an inverse relationship among them whereas default rate is the most predictor of bank financial performance.

A work done by Das (2012) revealed that in most of the banks, loan covers half or more of their total assets and about half to two-thirds of their revenues. However, Trust Bank Limited (TBL) maintains a diverse credit portfolio that contains different scheme loans. Furthermore, this bank as a matter of policy priority wants to ensure the quality of its Loan Portfolio by strengthening post disbursement recovery measures as well as by prioritizing on Early Warning System (EWS) to check the growth of non-performing assets.

According to Swartz (2013), Islamic banking is interest-free and primarily based on equity i.e. profit/loss sharing principles. To remain competitive, Islamic banks are to find out the risks and take actions to control them so that providers of capital and entrepreneur can share the risks and return.

Mosharrafa (2013) found that as an intermediary institution, Bank mobilizes surplus funds to the sectors which need it the most. The credit grading technique is an important tool for credit management because it helps to understand various dimensions of risk involved in different credit transactions of a bank. From the study of a well-known commercial bank's credit appraisal and risk grading technique, it is further found that it is necessary to maintain a standard credit policy in the changing situation of the financial market.

Hamdi and Zarai (2013) examined that Islamic banking institutions (IBIs) are more likely to use efficient earnings management (EM) or opportunistic EM. Besides, a positive and significant relationship between EM proxy and future profitability which means that EM tends toward efficiency.

Ahmed and Malik (2015) worked on the influence of credit risk management practices on investment performance (LP) considering the credit terms and policy (CTP), client appraisal, collection policy (CP) and credit risk control (CRC) as the dimensions of the credit risk management practices and found that the credit terms and client appraisal have a positive and significant impact on the LP, while the $\mathrm{CP}$ and $\mathrm{CRC}$ have a positive but insignificant impact on Loan Performance (LP).

Sabeza, Shukla, and Bajpai (2015) in their research assessed the relationship between credit risk management and banks' profitability. The result is that there is a direct relationship between credit risk management and the profitability of commercial banks in Rwanda.

Noman, Pervin, and Banna (2015) used NPLGL, LLRGL, LLRNPL and CAR as credit risk indicators and ROAA and ROAE and NIM as profitability indicators in their analysis and the findings are that a robust negative and significant effect of NPLGL, LLRGL on all 
profitability indicators and a negative and significant effect of CAR on ROAE. They further showed that the effect of the implementation of Basel II is significantly positive on NIM but significantly negative on ROAE.

Credit risk management $(\mathrm{CRM})$ includes identification, measurement, matching mitigations, monitoring and control of the credit risk exposure and the ideal CRM practices increase profitability and long-term sustainability of commercial banks found by Lalon (2015).

Mtaki and Ganesh (2016) in their work on loan management and risk practices in Banks found after reviewing the basic steps of loan management that there have mismanagements of loan practices in commercial banks. They further recommended that loan criteria and risk should be properly managed while offering loans.

Suzuki and Uddin (2016) found in their analysis that Islamic banking has experienced a paradigm shift from participatory financing to asset-based financing especially the Murabaha mode of financing that dominates Islamic banking.

Njeru, Mohhamed, and Wachira (2017) conducted a self-administered questionnaire through the drop and pick later method and used descriptive analysis. The results show that credit appraisal and credit terms have a substantial impact on the loan performance of commercial banks in Kenya. They also recommend that the character and collateral of the borrower should highly be weighted.

Hossain (2018) found that the performance analysis of Bangladesh Development Bank (BDBL) exhibits that loan recovery in an early stage of bank establishment was not satisfactory. After that, BDBL took effective Credit Risk Management initiatives such as the establishment of regional CRM Centers, the introduction of a new wing called Asset management and Credit inspection and so on.

Using the purposive sampling technique Olabamiji and Michael (2018) pointed out that credit management practices have a significant positive influence on the financial performance of First Bank, Nigeria. They further found that client appraisal, credit risk control, and collection policy are major predictors of financial performance.

The study by Islam, Alam, and Hossain found (2019) a positive association of Loan to Deposit Ratio (LTDR) with Return on Assets (ROA) and Return on Equity (ROE). On the contrary, the Loan-Loss Provision Ratio (LLPR) has a significant negative association with both ROA and ROE, while influencing Book value Ratio (MBR) positively. The study also indicates that the Geographic Focus Index (GFI) has a significant positive impact on Market-to MBR.

\section{DATA COLLECTION METHODOLOGY}

According to the objective that intends to examine the performance of investment management of Social Islami Bank Limited (SIBL) comprise of both qualitative and quantitative investigation. This study requires much information on how efficiently the bank manages its credit section by internalizing the associated risks, profitability and sustainability. To meet the purpose of the study, different sources of data relating to investment management need to be scrutinized. Besides, credit management policies and guidelines provided by Central Bank and their application by SIBL are to be well inspected in this endeavor. Therefore, the following procedure has to adopt for making the study.

\section{Research Design}

As par the nature of data, this is both a qualitative and quantitative analysis briefly uncovering the investment management performances of Social Islami Bank Limited (SIBL) and further 
unlocking the practices and patterns of loan management in Bangladesh. From the viewpoint of function as this research is based on the investment management department, it is descriptive in nature.

\section{Methods of Data Collection}

The Study is descriptive in nature. Most of the data have been collected from secondary sources. The secondary data is collected through the following means: internal Sources (such as annual report, official data book, official document, website of SIBL and other related online reports and journals, circulars, policies and guidelines prescribed by Bangladesh Bank (Bangladesh Bank [BB], 2020); External Sources (such as relevant books and journals, websites and articles).

\section{Presentation of Data}

As the nature of the study is both qualitative and quantitative collected data is processed and compiled in different charts, graphs and tables in the analysis part of the research. The universal research writing software Microsoft office was used to process all necessary writing, calculations and tables.

\section{ANALYSIS AND DISCUSSION}

The Analysis of Capital and Growth Rate of the Last 5 Years

Table 1. Capital and Growth Rate (\%) of Last 5 Years

(In Million Tk.)

\begin{tabular}{|l|c|c|c|l|}
\hline Years & Paid Up Capital & Total Capital & Growth rate & \multicolumn{1}{|c|}{ Sources of Capital } \\
\hline 2015 & $7,031.42$ & $16,916.08$ & $29.34 \%$ & Internal generation \\
\hline 2016 & $7,385.99$ & $19,195.04$ & $13.47 \%$ & Internal generation \\
\hline 2017 & $7,385.99$ & $21,725.08$ & $13.18 \%$ & Internal generation \\
\hline 2018 & $8,121.29$ & $26,111.51$ & $20.19 \%$ & Internal generation \\
\hline 2019 & $8,933.41$ & $27,901.80$ & $6.86 \%$ & Internal generation \\
\hline
\end{tabular}

Source: Annual Report of SIBL (2015-2019)

Interpretation: The above table shows that although the amount of paid-up capital in SIBL has been increased from 2015 to 2019, the growth rate of the company drastically falls in 2019 despite the slight increase in 2018. This indicates the overall performance of the bank is not up to the mark. In this regard, the investment performance is scrutinized thoroughly below to know which segment of investment management affects the overall performance of the bank.

Analysis of Total Investment and Growth Rate (\%) of Last 5 Years

Table 2. Total Investment and growth rate (\%) of Last 5 Years

(In Million Tk.)

\begin{tabular}{|c|c|c|}
\hline Year & Total Investment & Growth Rate (\%) \\
\hline $\mathbf{2 0 1 5}$ & $134,116.90$ & $24 \%$ \\
\hline $\mathbf{2 0 1 6}$ & $174,196.10$ & $30 \%$ \\
\hline $\mathbf{2 0 1 7}$ & $210,045.51$ & $21 \%$ \\
\hline $\mathbf{2 0 1 8}$ & $238,654.17$ & $14 \%$ \\
\hline $\mathbf{2 0 1 9}$ & $264,268.59$ & $11 \%$ \\
\hline
\end{tabular}

Source: Annual Report of SIBL (2015-2019) 


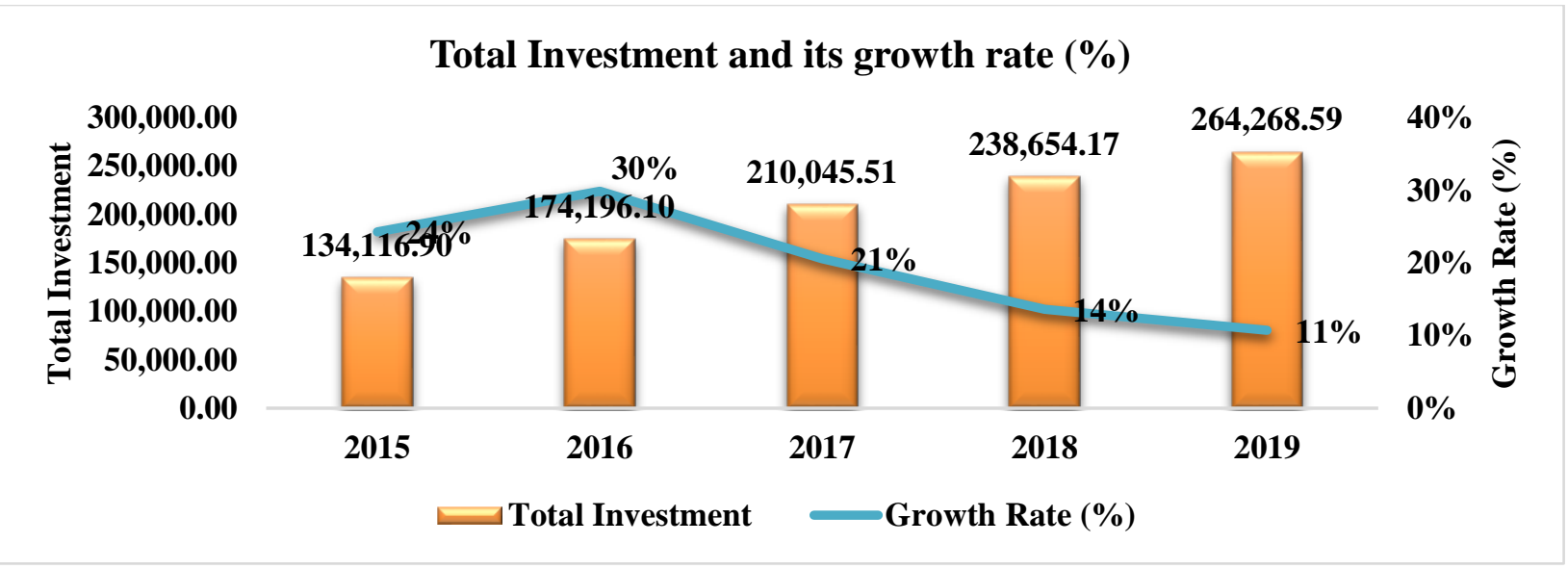

Figure 1. Investment Growth Rate (\%) of the Last 5 Years

Interpretation: The above figures show that the amount of investment increased from Tk.134116.9 million to Tk. 174196.1 million from 2015 to 2016 at an almost 6\% rate. The amount of investment also increased to Tk.210045.51 million in 2017 and Tk. 238654.17 million in 2018 but the growth rate fell by $9 \%$ in each year. The amount further increased to Tk. 264268.59 million in 2019 with a negative growth rate of $7 \%$ and a positive growth rate of $3 \%$ in 2018 and 2019 respectively. Therefore, it can be said that the investment scenario is fluctuated over the years and adversely affected the bank.

Analysis of Total Deposit and Growth Rate (\%) of Last 5 Years

Table 3. Total Deposit and Growth Rate (\%) of Last 5 Years

\begin{tabular}{|c|c|c|}
\hline Year of Deposit & Total Deposit & Growth Rate (\%) \\
\hline 2015 & $149,773.60$ & $20 \%$ \\
\hline 2016 & $190,564.50$ & $27 \%$ \\
\hline 2017 & $228,798.90$ & $20 \%$ \\
\hline 2018 & $248,324.49$ & $9 \%$ \\
\hline 2019 & $287,936.65$ & $16 \%$ \\
\hline
\end{tabular}

Source: Annual Report of SIBL (2015-2019)

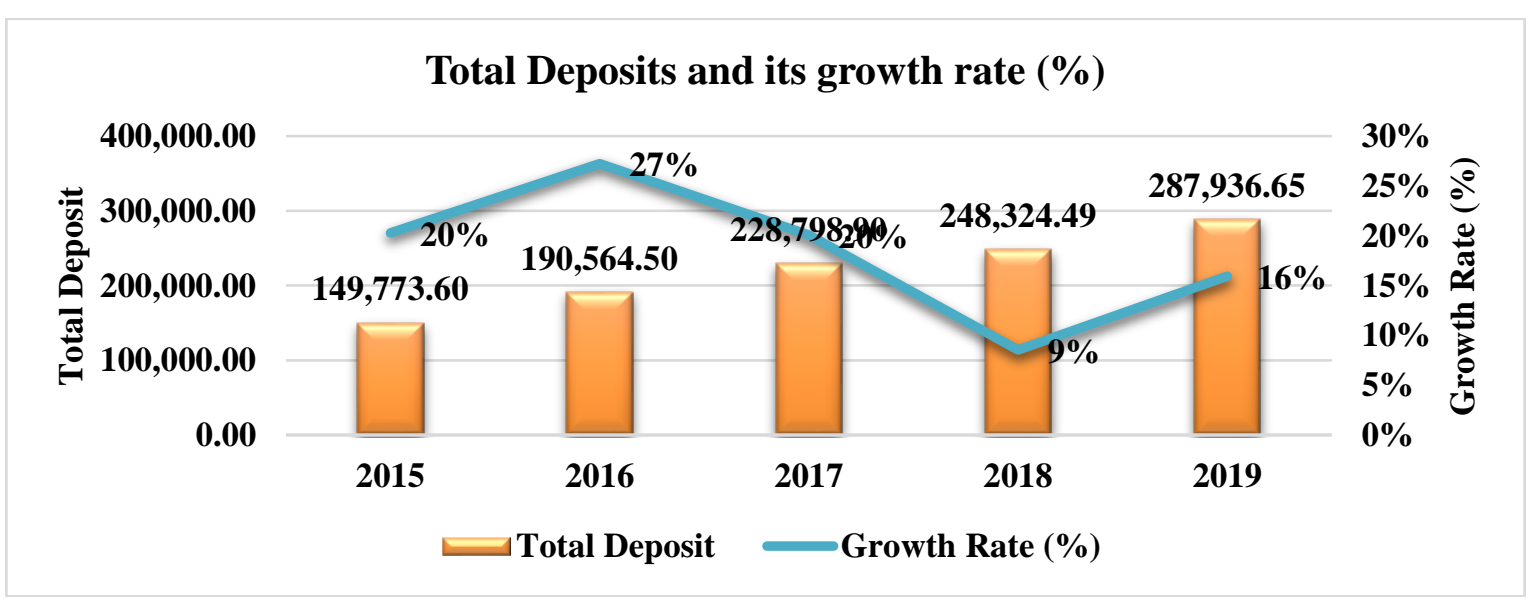

Figure 2. The Amount of Total Deposit Growth rate (\%) of the Last 5 Years 
Interpretation: The above graphs signify that the amount of deposit increases over the years due to the expansion of new branches and customers. However, fluctuation in deposit growth rate is observed. The highest growth of deposit (27\%) is attained in the year 2016 when the amount was Tk. 190564.5 million. And the lowest growth rate (9\%) is observed in 2018 when the amount was Tk. 248324.49 million. It is a good sign that the growth of deposits is increased positively $(16 \%)$ in 2019.

Table 4. Investment-Deposit ratio of the Last 5 Years

\begin{tabular}{|c|c|c|c|c|c|}
\hline Year & $\mathbf{2 0 1 5}$ & $\mathbf{2 0 1 6}$ & $\mathbf{2 0 1 7}$ & $\mathbf{2 0 1 8}$ & $\mathbf{2 0 1 9}$ \\
\hline Investment & $134,116.90$ & $174,196.10$ & $210,045.51$ & $238,654.17$ & $264,268.59$ \\
\hline Deposit & $149,773.60$ & $190,564.50$ & $228,798.90$ & $248,324.49$ & $287,936.65$ \\
\hline Investment/Deposit & $90 \%$ & $91 \%$ & $92 \%$ & $96 \%$ & $92 \%$ \\
\hline
\end{tabular}

Source: Annual Report of SIBL (2015-2019)

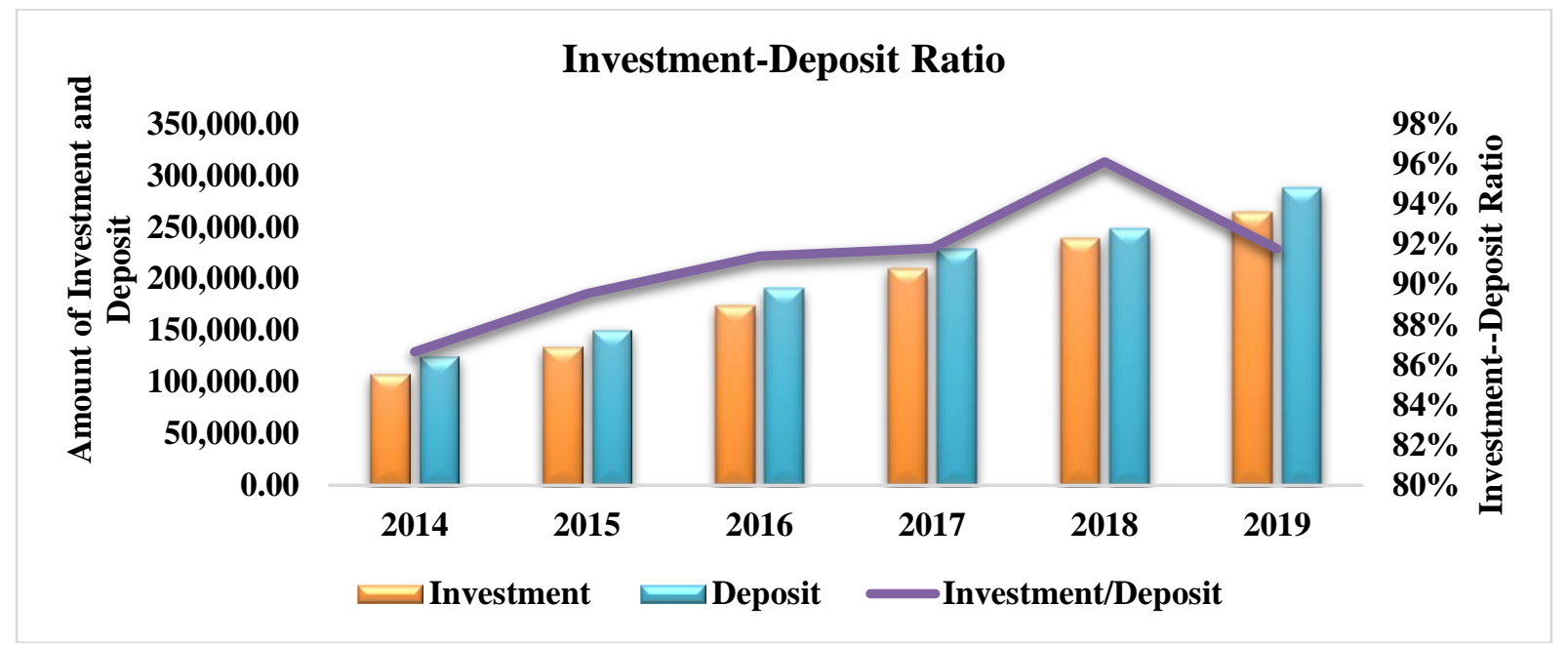

Figure 3. Investment Deposit ratio of the Last 5 Years

Interpretation: The amount of investment in terms of the deposit is satisfactory over the five years and the growth rate is also more than $90 \%$ which indicates a very good investment-deposit performance. However, a slight decrease in the percentage of the investment-deposit ratio is observed in 2019 which is $92 \%$.

Analysis of Different Mode Wise Investment

Table 5. Amount of Investment for Different Modes from 2015 to 2019.

(In Million Tk.)

\begin{tabular}{|l|l|l|l|l|l|}
\hline \multicolumn{7}{|c|}{ Amount of Investment } \\
\hline \multicolumn{1}{|c|}{ Modes } & \multicolumn{1}{|c|}{$\mathbf{2 0 1 5}$} & \multicolumn{1}{|c|}{$\mathbf{2 0 1 6}$} & \multicolumn{1}{c|}{$\mathbf{2 0 1 7}$} & \multicolumn{1}{c|}{$\mathbf{2 0 1 8}$} & \multicolumn{1}{c|}{$\mathbf{2 0 1 9}$} \\
\hline Musharaka & $493,698,920$ & $394,014,125$ & $406,944,059$ & $347,714,917$ & $285,826,612$ \\
\hline Bai-Murabaha & $3,929,937,139$ & $3,923,518,808$ & $4,453,662,291$ & $3,889,304,111$ & $4,110,909,296$ \\
\hline Mudaraba & $4,525,723,316$ & $6,890,919,882$ & $6,593,469,910$ & $2,061,861,392$ & $2,213,479,499$ \\
\hline Bai-Muazzal & $77,429,002,878$ & $103,157,036,645$ & $126,947,350,897$ & $157,973,557,142$ & $175,173,237,666$ \\
\hline
\end{tabular}




\begin{tabular}{|l|l|l|l|l|l|}
\hline Bai-Salam & $340,927,788$ & $499,755,394$ & $596,285,547$ & $775,677,519$ & $931,350,622$ \\
\hline HPSM & $28,685,850,999$ & $39,236,072,051$ & $50,888,743,949$ & $54,779,810,323$ & $56,906,637,122$ \\
\hline Quard & $6,044,230,063$ & $9,867,948,969$ & $9,213,891,287$ & $6,850,181,947$ & $8,648,705,103$ \\
\hline Staff Loan & $1,758,314,744$ & $2,222,858,996$ & $2,463,571,391$ & $2,385,978,089$ & $2,431,330,908$ \\
\hline Ijara & $146,666,764$ & $327,654,954$ & $436,132,387$ & $660,073,348$ & $609,610,142$ \\
\hline Visa Card & $275,775,541$ & $481,551,356$ & $682,832,475$ & $710,835,809$ & $727,898,260$ \\
\hline
\end{tabular}

Source: Annual Report of SIBL (2015-2019)

\section{Amount of Investment for Different Modes}

\section{$700,000,000,000$ $600,000,000,000$ $500,000,000,000$ $400,000,000,000$ $300,000,000,000$ 200,000,000,000 $100,000,000,000$}
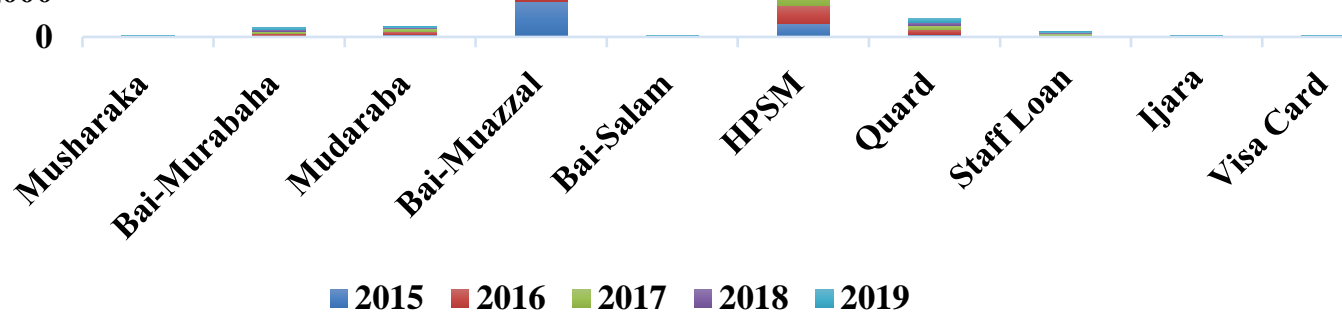

Figure 4. Amount of Investment for Different Modes

Table 6. Percentage of Investment for Different Modes from 2016 to 2019

(In Million Tk.)

\begin{tabular}{|l|c|c|c|c|c|}
\hline \multicolumn{7}{|c}{ Percentage of Amount of Investment } \\
\hline Modes & $\mathbf{2 0 1 5}$ & $\mathbf{2 0 1 6}$ & $\mathbf{2 0 1 7}$ & $\mathbf{2 0 1 8}$ & $\mathbf{2 0 1 9}$ \\
\hline Musharaka & $0.40 \%$ & $0.24 \%$ & $0.20 \%$ & $0.15 \%$ & $0.11 \%$ \\
\hline Bai-Murabaha & $3.18 \%$ & $2.35 \%$ & $2.20 \%$ & $1.69 \%$ & $1.63 \%$ \\
\hline Mudaraba & $3.66 \%$ & $4.13 \%$ & $3.25 \%$ & $0.89 \%$ & $0.88 \%$ \\
\hline Bai-Muazzal & $62.63 \%$ & $61.77 \%$ & $62.63 \%$ & $68.55 \%$ & $69.50 \%$ \\
\hline Bai-Salam & $0.28 \%$ & $0.30 \%$ & $0.29 \%$ & $0.34 \%$ & $0.37 \%$ \\
\hline HPSM & $23.20 \%$ & $23.49 \%$ & $25.11 \%$ & $23.77 \%$ & $22.58 \%$ \\
\hline Quard & $4.89 \%$ & $5.91 \%$ & $4.55 \%$ & $2.97 \%$ & $3.43 \%$ \\
\hline Staff Loan & $1.42 \%$ & $1.33 \%$ & $1.22 \%$ & $1.04 \%$ & $0.96 \%$ \\
\hline Ijara & $0.12 \%$ & $0.20 \%$ & $0.22 \%$ & $0.29 \%$ & $0.24 \%$ \\
\hline Visa Card & $0.22 \%$ & $0.29 \%$ & $0.34 \%$ & $0.31 \%$ & $0.29 \%$ \\
\hline
\end{tabular}

Source: Annual Report of SIBL (2015-2019) 


\section{Percentage of Amount of Investment for Different Modes}

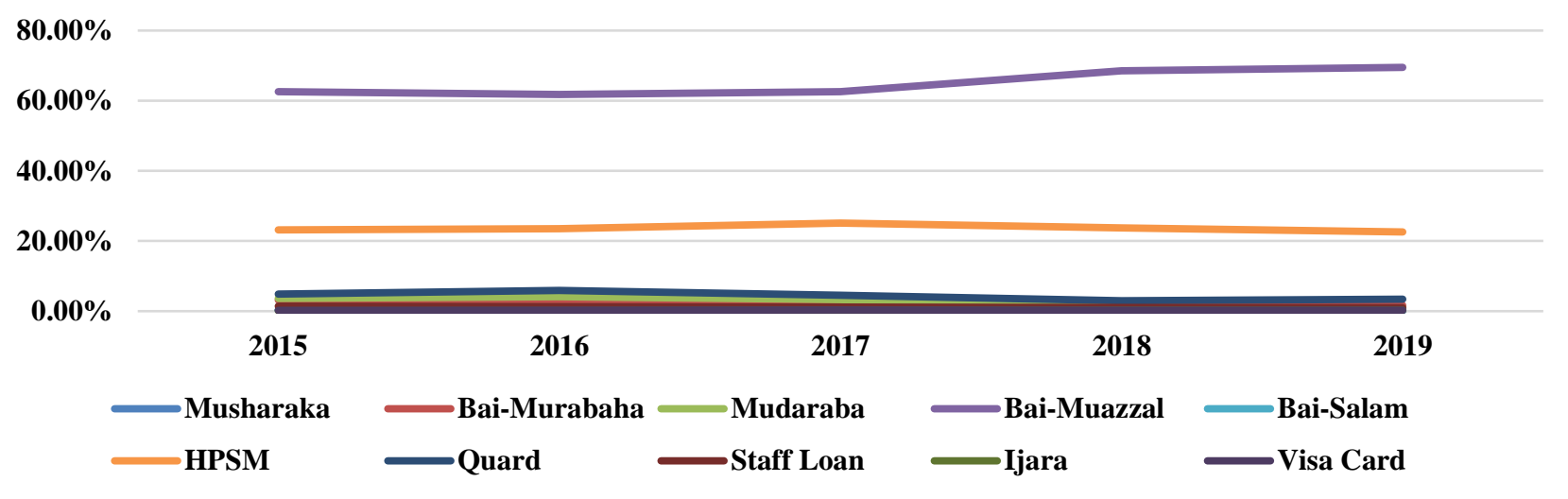

Figure 5. Percentage of Amount of Investment for Different Modes

Interpretation: The amount of investment in Musharaka falls after 2017 continuously while the growth rate also started to decline after the year 2016. The amount of investment in BaiMurabaha mode reflects a negative trend from 2015 to 2016. After that, the amount of investment was high in 2017 which rapidly fell in 2018 but was in increasing trend in the year 2019. Additionally, it shows a negative percentage of invested amount over the year. There is an upward trend of investment in Mudaraba mode from 2015 to 2016 after that a downward trend remains consistent from 2016 to 2018 with a slight increase in investment amount in 2019. Therefore, it remains as an unstable mode of investment. Bai- Muazzal is the investment mode where both the amount of investment and its share increase over five years. It is observed that the percentage share of Bai-Muazzal has lightly decreased from $62.63 \%$ to $61.17 \%$ but later on it has an increase by $68.55 \%$ in 2019. Despite the increase in the amount of Hire Purchase Under Shirkatul Melk (HPSM), its percentage share has its highest in the year 2017 and its lowest in 2019. It can be observed that there is a fluctuation in the amount invested in Quard mode. However, there was an increase in the percentage share of investment from 2015 to 2016 and a reduction from 2016 to 2018. In 2019, both amount and its share show an upward trend. Furthermore, it is clear from the above graph that both the amount of investment and the share of investment for Bai-Salam is on increase over the periods. The investment has increased from Tk. $340,927,788$ million in 2015 to Tk. 931,350,622 million and the percentage of share of investment also increased from $0.28 \%$ to $0.37 \%$ for the same periods. In case of staff oans, it increases at a decreasing rate over the last 5 years. In 2015 its share of investment was 1.42\% and it was $0.96 \%$ in 2019. The highest amount of investment in Ijarah i.e. Tk. 660,073,348 million was made in 2018. The increasing trend of share of investment was there for the year 2015 to 2018. In 2019, it has decreased. The investment in visa card mode is increasing over the years. However, the share of investment is observed to be lower.

Table 7. Amount of Profit for Different Modes from 2016 to 2019

(In Million Tk.)

\begin{tabular}{|l|c|c|c|c|c|}
\hline \multicolumn{7}{|c|}{ Yearly Amount of Profit } \\
\hline Modes & $\mathbf{2 0 1 5}$ & $\mathbf{2 0 1 6}$ & $\mathbf{2 0 1 7}$ & $\mathbf{2 0 1 8}$ & $\mathbf{2 0 1 9}$ \\
\hline Musharaka & 51.15 & 38.94 & 31.3 & 38.16 & 32.44 \\
\hline Mudaraba & 238.98 & 236.94 & 160.52 & 97.46 & $\mathbf{2 3 . 8 8}$ \\
\hline
\end{tabular}




\begin{tabular}{|l|c|c|c|c|c|} 
Bai-Murabaha & 195.23 & 119.86 & 120.12 & 195.44 & 206.04 \\
\hline Bai-Muazzal & $8,828.93$ & $10,118.43$ & $11,235.98$ & $15,878.29$ & $18,263.67$ \\
\hline Bai Salam & 13.63 & 40.66 & 57.21 & 69.78 & 83.03 \\
\hline HPSM & $2,692.87$ & $3,876.45$ & $4,865.04$ & $6,275.72$ & $6,379.69$ \\
\hline Quard & 766.35 & 557.89 & 582.61 & 533.59 & 532.99 \\
\hline Ijarah & 16.34 & 27.31 & 42.58 & $\mathbf{5 5 . 3 2}$ & 79.42 \\
\hline Visa Cards & 153.28 & 217.78 & 250.31 & 235.66 & 213.65 \\
\hline Other & 2332.11 & 1649.14 & 1151.95 & 1576.45 & 1982.61 \\
\hline Total & $15,288.87$ & $16,883.40$ & $18,497.62$ & $24,955.87$ & $27,797.42$ \\
\hline
\end{tabular}

Source: Annual Report of SIBL (2015-2019)

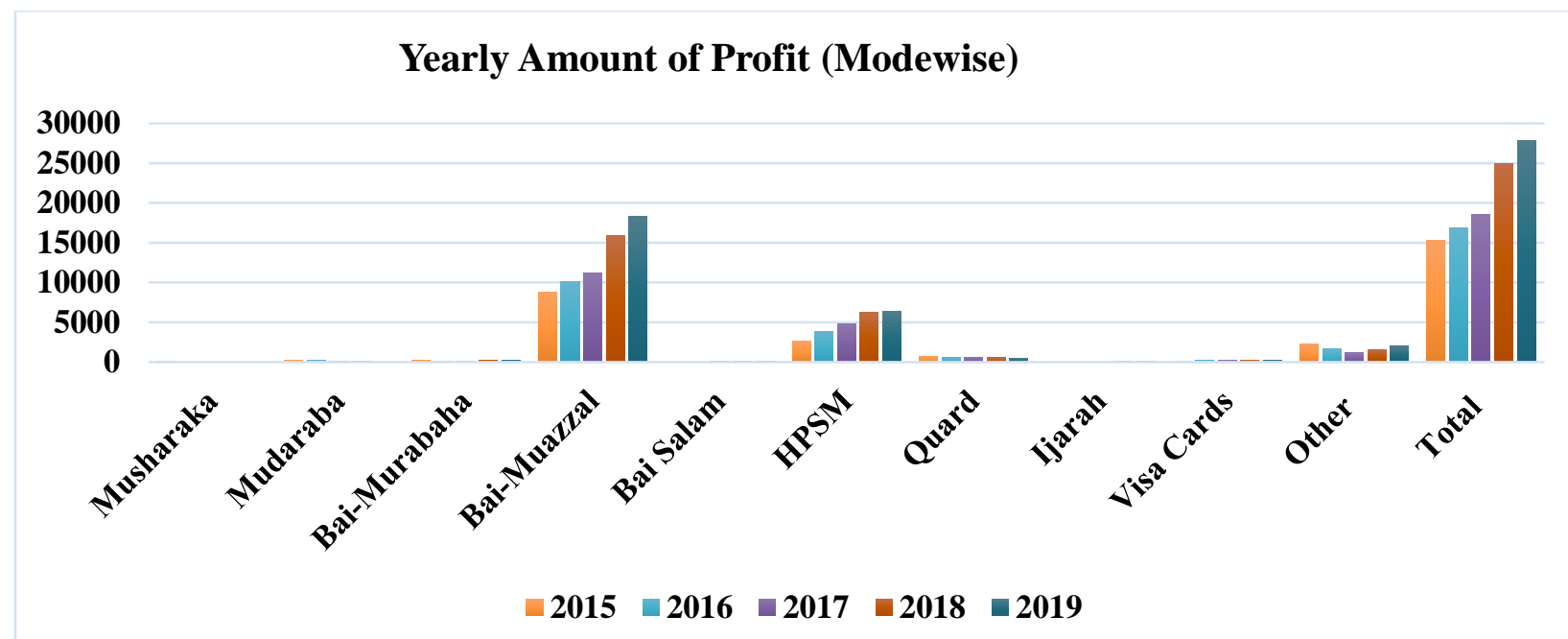

Figure 6. Yearly Amount of Profit for different Modes

Interpretation: The decreasing amount of investment in Musharaka mode reflects a decreasing profit over the year from 2015 to 2019. Therefore, it is a negative profit-earning mode of investment. In case of Bai-Murabaha, the trend of percentage share of profit is observed to be fluctuated over the last five years because the amount of investment showed the same characteristics. Despite the fluctuation of the investment in Mudaraba mode, the trend of share of profit shows a sharp downturn over the years. Therefore, it can be said that the profitability of this mode is negative. It is observed from the graph that Bai- Muazzal has a positive amount of profit and a skyrocketing percentage share of profit trend. The percentage share of profit has increased from $57.75 \%$ to $65.70 \%$ over years. Therefore, it can be said that Bai-Muazzal is the high profit-making mode of investment for SIBL. The amount of profit of HPSM has increased from Tk. 2692.87 million in 2015 to Tk.6379.69 million in 2019. The shared profit shows a concave shape. The highest percentage share was $26.30 \%$ in 2017 and in 2019, it shows a decreasing trend. The graph Quard shows that the amount and the share of profit have decreased over the periods. Despite the increase in the amount of investment, the share of profit faces a reduction in 2019. Therefore, it can be said that it a decreasing profit-earning mode of investment for the bank. Increased amount of investment of Bai-salam induces the amount of profit. However, there was a trough in profit in 2018. There is an overall increase in the share of profit of around $0.21 \%$ in the last five years. This mode of investment can be categorized as a 
high profit earning mode of investment. Ijarah shows an increasing profit rate from 2015 to 2017. Later it has decreased to $0.22 \%$ from $0.23 \%$. However, at the end of 2019 , it was $0.29 \%$. In short, this mode of investment has ended 2019 with a positive return of profit.It is seen that profit on the card was on increasing from 2015 to 2017 and experienced a downward trend up to 2019. The amount of profit earned on the card was Tk. 213.65 which was less among the last 5 years.

There are some other mods of investment such as inland and foreign bill purchased as well as Mudaraba deposit with other banks. Although this investment is a trifle, the profit earned on these modes of investment has a significant impact on the bank. Profit on Inland Bill purchased is increasing whereas the foreign Inland Bill purchase has a high profit compared to that of the last two years and so is the profit on foreign document bill purchased

Table 8. Percentage of Profit for Different Modes from 2016 to 2019.

\begin{tabular}{|l|c|c|c|c|c|}
\hline \multicolumn{7}{|c|}{ Yearly Profit Growth Rate in percentage } \\
\hline Modes & $\mathbf{2 0 1 5}$ & $\mathbf{2 0 1 6}$ & $\mathbf{2 0 1 7}$ & $\mathbf{2 0 1 8}$ & $\mathbf{2 0 1 9}$ \\
\hline Musharaka & $4.32 \%$ & $-23.87 \%$ & $-19.62 \%$ & $21.92 \%$ & $-14.99 \%$ \\
\hline Mudaraba & $-10.31 \%$ & $-0.85 \%$ & $-32.25 \%$ & $-39.28 \%$ & $-75.50 \%$ \\
\hline Bai-Murabaha & $-22.64 \%$ & $-38.61 \%$ & $0.22 \%$ & $62.70 \%$ & $5.42 \%$ \\
\hline Bai-Muazzal & $16.54 \%$ & $14.61 \%$ & $11.04 \%$ & $41.32 \%$ & $15.02 \%$ \\
\hline Bai-Salam & $259.63 \%$ & $198.31 \%$ & $40.70 \%$ & $21.97 \%$ & $18.99 \%$ \\
\hline HPSM & $21.76 \%$ & $43.95 \%$ & $25.50 \%$ & $29.00 \%$ & $1.66 \%$ \\
\hline Quard & $-13.57 \%$ & $-27.20 \%$ & $4.43 \%$ & $-8.41 \%$ & $-0.11 \%$ \\
\hline Ijarah & $-12.01 \%$ & $67.14 \%$ & $55.91 \%$ & $29.92 \%$ & $43.56 \%$ \\
\hline Visa Cards & $-43.92 \%$ & $42.08 \%$ & $14.94 \%$ & $-5.85 \%$ & $-9.34 \%$ \\
\hline Other & $-3.50 \%$ & $-29.29 \%$ & $-30.15 \%$ & $36.85 \%$ & $25.76 \%$ \\
\hline Total & $9.65 \%$ & $10.43 \%$ & $9.56 \%$ & $34.91 \%$ & $11.39 \%$ \\
\hline
\end{tabular}

Source: Annual Report of SIBL (2015-2019)

\section{Yearly Profit Growth Rate in Percentage (Modewise)}

$300.00 \%$

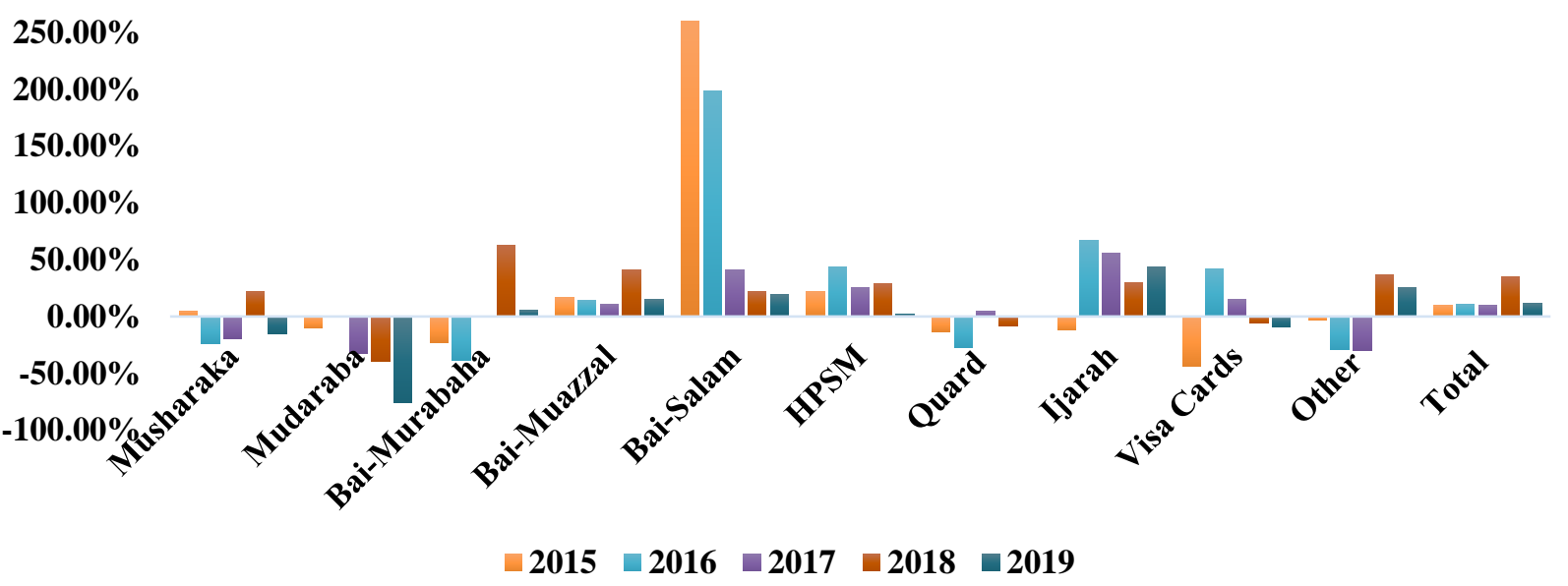

Figure 7. Yearly Profit Growth Rate in Percentage for different Modes 
Interpretation: The above graph shows the profit growth rate of different investment mode from 2015 to 2019. It is clear from the data that among the investment modes Bai-Muazzal, HPSM and Bai- Salam indicated a positively fluctuated growth rate of income which has a positive impact on total income. On the other hand, Bai-Murabaha, Musharaka, Quard, Ijarah, Visa cards and Mudaraba showed negatively fluctuated growth rate of income which affects total income. It is further observed that total income had a positive growth highest growth in 2015 (9.65\%) t0 $2016(10.43 \%)$ and had the highest growth (34.91\%) in 2018 but experienced a reduction in $2019(11.39 \%)$.

Financial Analysis of Classified and Unclassified Investment

Table 9. Amount and Percentage of Classified Investment

\begin{tabular}{|c|c|c|c|c|c|}
\hline $\begin{array}{c}\text { Type of } \\
\text { Investment }\end{array}$ & $\mathbf{2 0 1 5}$ & $\mathbf{2 0 1 6}$ & $\mathbf{2 0 1 7}$ & $\mathbf{2 0 1 8}$ & $\mathbf{2 0 1 9}$ \\
\hline $\begin{array}{c}\text { Classified } \\
\text { Investment }\end{array}$ & $5,149,577,421$ & $7,738,196,000$ & $17,227,098,188$ & $18,350,990,000$ & $17,533,303,838$ \\
\hline $\begin{array}{c}\text { Total } \\
\text { Investment }\end{array}$ & $134,116,849,903$ & $174,196,133,375$ & $210,045,509,085$ & $238,654,170,953$ & $264,268,589,649$ \\
\hline $\begin{array}{c}\text { Ratio of } \\
\text { Classified } \\
\text { Investments } \\
\text { to Total } \\
\text { Investments }\end{array}$ & $3.84 \%$ & $4.44 \%$ & $8.20 \%$ & $7.69 \%$ & $6.63 \%$ \\
\hline
\end{tabular}

Source: Annual Report of SIBL (2015-2019)

\section{Year Wise Amount and ratio of Classified Investment}

$300,000,000,000$

$250,000,000,000$

$200,000,000,000$

$150,000,000,000$

$100,000,000,000$

$50,000,000,000$

o

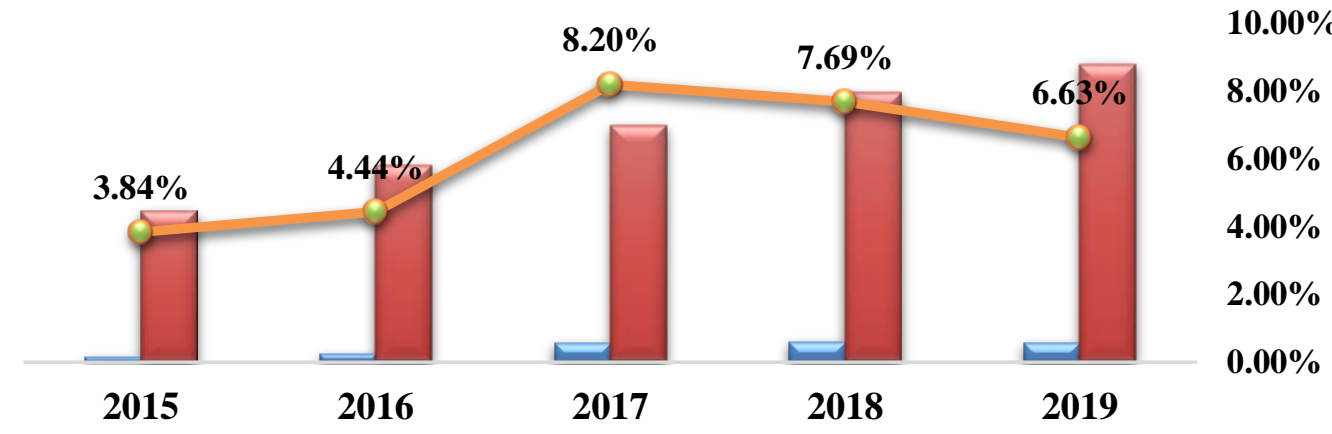

Classified Investment

Total Investment

- Ratio of Classified Investments to Total Investments

Figure 8. Amount and ratio of Classified Investment of Last 5 Years

Interpretation: The above graph shows the year-wise amount and ratio of classified investment. It indicates the volume of classified investment increased over the years. However, the ratio of investment has risen to $6.20 \%$ in 2017 from $3.84 \%$ in 2015 and fell to $6.63 \%$ in 2019 when the volume was Tk. 17,533,303,838. The highest number of defaults is observed in 2017 though the recovery is seen to be developed in the last two years. But the performance is slowly improving. 
Table 10. Amount of Different Classified Investment

(In Million Tk.)

\begin{tabular}{|l|l|l|l|l|l|}
\hline \multicolumn{1}{|c|}{ Status } & $\mathbf{2 0 1 5}$ & $\mathbf{2 0 1 6}$ & $\mathbf{2 0 1 7}$ & $\mathbf{2 0 1 8}$ & $\mathbf{2 0 1 9}$ \\
\hline $\begin{array}{l}\text { Sub Standard Investment } \\
\text { (SS) }\end{array}$ & 640.78 & 314.42 & $1,806.33$ & 656.49 & 699.25 \\
\hline Doubtful Investment (DF) & 92.8 & $1,363.48$ & $1,421.22$ & 739.88 & 283.28 \\
\hline Bad or Loss investment (BL) & $4,415.99$ & $6,060.30$ & $13,999.55$ & $16,954.63$ & $16,550.77$ \\
\hline Total Classified Investment & 5149.57 & 7738.2 & 17227.1 & 18351 & 17533.3 \\
\hline $\begin{array}{l}\text { Total Provision on Classified } \\
\text { Investment }\end{array}$ & 1673.41 & 1764.69 & 3473.74 & 6398.01 & 7595.56 \\
\hline
\end{tabular}

Source: Annual Report of SIBL (2015-2019)

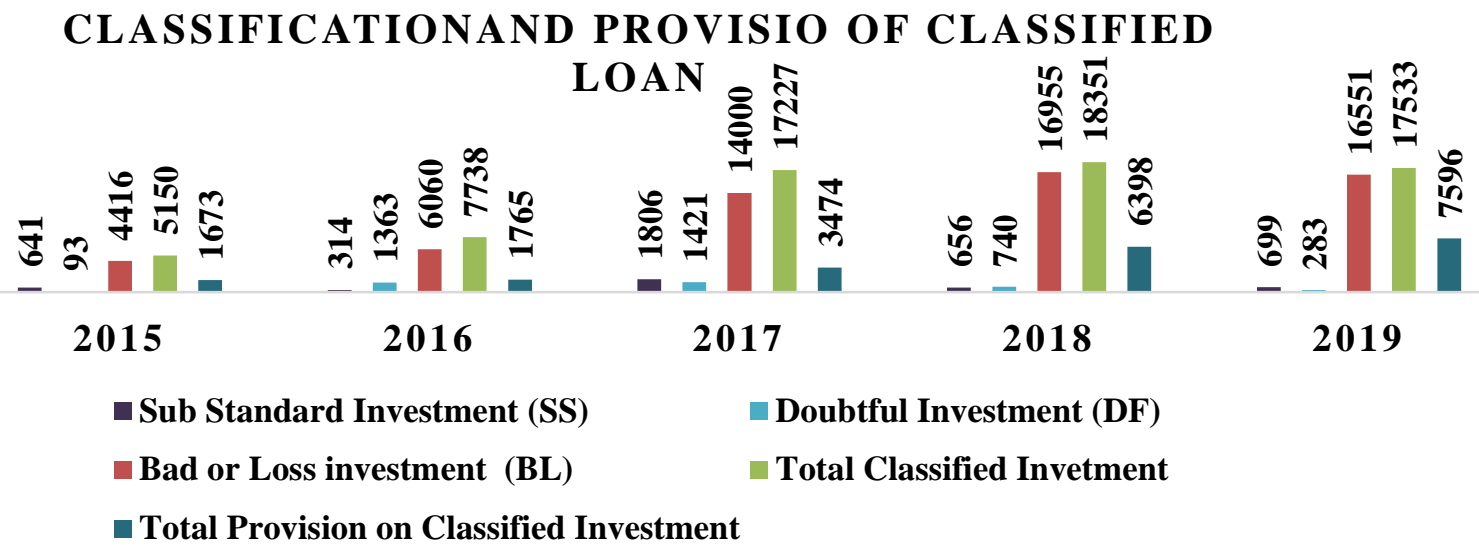

Figure 9. Classification and Provision of Classified Loan of Last 5 Years

Interpretation: The above graph shows that the major portion of classified investments is in the category of bad or loss investment. The sub-standard investment is on the rise. The doubtful investment is on was highest in 2017. After that, the figure started reducing. However, there is no significant change in the figure of bad or loss investment observed. The provision of classified investment has increased from Tk 1673 million in 2015 to Tk. 7596 million in 2019. It indicates the inefficiency in investment management.

Table 11. Ratio of Unclassified Investment in terms of Total Investment

\begin{tabular}{|c|c|c|c|c|c|}
\hline Type of Investment & $\mathbf{2 0 1 5}$ & $\mathbf{2 0 1 6}$ & $\mathbf{2 0 1 7}$ & $\mathbf{2 0 1 8}$ & $\mathbf{2 0 1 9}$ \\
\hline Unclassified Investment & 126830 & 162645 & $187125 \mathrm{i}$ & 215691 & 242355 \\
\hline Total Investment & $134,116.90$ & $174,196.10$ & $210,045.51$ & 238,654 & $264,268.59$ \\
\hline $\begin{array}{c}\text { Ratio of Unclassified } \\
\text { Investments to Total } \\
\text { Investments }\end{array}$ & $94.57 \%$ & $93.37 \%$ & $89.09 \%$ & $90.38 \%$ & $91.71 \%$ \\
\hline
\end{tabular}

Source: Annual Report of SIBL (2015-2019) 


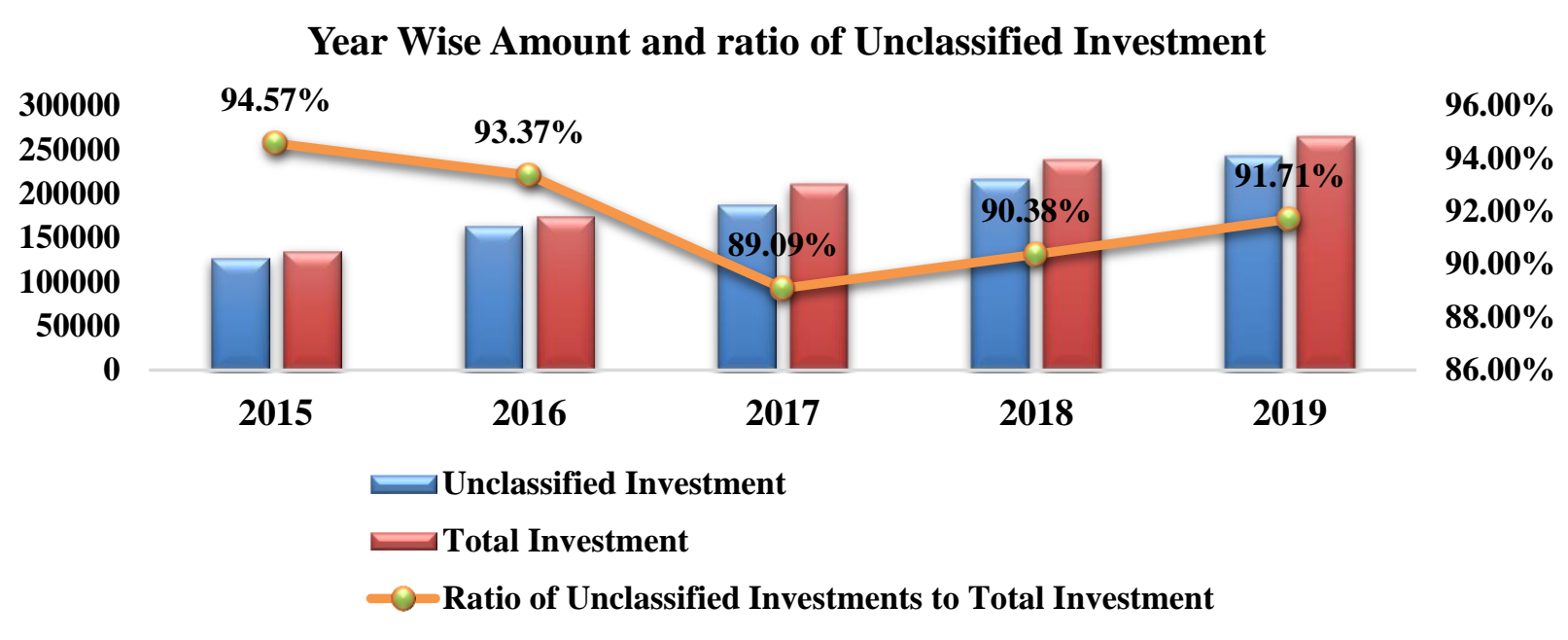

Figure 10. Amount and Ratio of Unclassified Investment of Last 5 Years

Interpretation: SIBL performed badly when the classified investment was reduced to $89.99 \%$ in 2017 from $94.57 \%$ in 2015 . Later on, it has increased to $91.71 \%$ in 2019 which is a good indication of investment management.

\section{MAJOR FINDINGS}

- The amount of deposit has increased over the years. However, Fluctuation in the growth rate of deposit is observed. It was $20 \%$ and $27 \%$ in 2015 and 2016. Later, it started decreasing by $20 \%$ to $9 \%$ from 2017 to 2018 . But the growth showed a positive trend from 2019 i.e. $16 \%$.

- The amount of total investment also increased over the period. However, the growth rates faced fluctuations. It was 24\%, 30\% in 2015 and 2016 respectively. After the growth followed a decreasing trend from 2017 to 2019.

- The investment mode of Bai-Muazzal, Bai-Salam are comparatively ideal mode than BaiMurabaha. It indicates better performance in the case of the Bai-Muazzal and Bai-Salam mode of investment though the rate of return of this mode positively fluctuated.

- As it is observed that return of Mudaraba was always reducing from 2015 to 2019 despite increasing the amount of investment. Therefore, it indicates that there was poor management of Mudaraba mode.

- In the case of Musharaka mode, the bank reduced the investment amount slightly over the years but the return decreased at a decreasing rate. Therefore, the clients and the company feel reluctant to invest in this bank. This implies that the bank showed inefficiency in managing this mode.

- The amount invested in HPSM mode increased over the periods and the amount of profit also increased from Tk. 2692.87 million in2015 to Tk. 6379.69 million in 2019. Bank showed proficiency in managing this mode.

- Ijarah is also found to be the positively profit-making mode of investment because the profit amount increased with the amount of investment.

- Murabaha has on average increasing profit over the periods despite fluctuations in the amount the investment. Whereas the Visa card earns lesser profit with a higher amount of 
investment. Therefore, it can be said that the Bank was more efficient in handling Murabaha than Visa Cards.

- The ratio of classified investment has risen to $8.20 \%$ in 2017 from $3.84 \%$ in 2015. After that, the ratio decreased to $6.63 \%$ in 2019 . That happens due to an increasing amount of sub-standard and bad or loss investment up to 2017. After that, the amount of substandard and bad loss fell which causes the reduction in the total ratio of classified and total investment. In essence, the performance of classified investment management is improving at a slower pace after 2017.

- On the other hand, the ratio of unclassified investment in terms of total investment always remained above $90 \%$ which signifies their management efficiency.

\section{RECOMMENDATIONS}

After realizing the analysis of the performance of investment management, some following recommendations can be made. They are-

- Although the amount of deposit increased, its growth rate decreased in the last two years compared to previous years of analysis. Therefore, the bank should focus on increasing the rate of growth of deposits by creating new schemes, opening branches and developing relationships with customers so that more funds can be made available for investment.

- The amount of investment is seen to be increasing at a decreasing rate. Therefore, the bank should develop new investment modes and manage both classified and unclassified investments maintaining the provisions provided by the central bank. The bank should also focus on efficient Portfolio management.

- The bank should increase the investment in an unclassified investment where a safe return is possible. However, they are aware of the ratio of unclassified investment to total investment to be categorized as good banking.

- The bank should be conscious about investing in classified investment window. The bank should develop a strong monitoring and evaluation cell so that risk can be minimized and the highest return can be achieved.

- The bank should invest in the modes where the bank earns higher profit over the periods with reduced risks such as Bai-Muazzal, Bai-Salam and HPSM. They should look for further investment modes that generate higher income with lower risks.

- The bank should concentrate on the rate of growth of profit. If the increasing trend of growth can be maintained, the bank will progress rapidly.

- It should connect people of home and abroad by Islamic banking. They should find safe investment zones both foreign as well as home.

- The bank should invest carefully in the modes where there are lower profits generated by investing a higher amount. If they do, they should invest after proper evaluation and analysis. It is seen that the bank generates lower income from Mudaraba, Musharaka and Quard investment mode.

- The bank should develop new investment schemes as well as partners. They should further focus on the creditworthiness of customers, ventures and schemes to earn positive growth for the bank

- They should develop programs by which the mass people can be attracted to the core values, practices and investment packages of Islamic banking. The bank should go to remote areas to cover village people by this banking. 
- Above all, the bank should focus on its strength and its weakness by proper management, regulation and direction by the skilled and talented board of directors.

\section{CONCLUSION}

As a second-generation commercial bank, SIBL is based on Shariah-principles providing the latest customer service excellence with deposit management and quality and secured investment services to the people by developing strategy and policies. Bank further always tries to maximize the shareholder's wealth while protecting other stakeholders' interests. The bank is also committed to maintain corporate governance and internal control system, corporate social responsibilities (CSR) and follow the rules and regulations provided by Bangladesh Bank and the corporate governance code provided by Securities and Exchange commissions of Bangladesh (BSEC). SIBL as a responsible institution has a huge spillover economic impact on the economic growth and development of the country year to year.

Over the years, the success of SIBL remains in improving asset quality, sustainable growth of profit and managing classified and unclassified investment below $6.63 \%$ compared to the industry average of $9.32 \%$. The bank has a strong mind set up to include the underprivileged people of society in the mainstream by providing SME and finance.

SIBL as a bank always tries to possess a true, fair and strong financial position over the periods. After observation and analysis, it can be said that Social Islami Bank (SIBL) has been a profitable bank from 2015 to 2019 through efficient management of the bank especially following the well-mannered investment principles. However, their investment management has been gone through volatilities over the last five years. Starting with a growth of $24 \%$ in 2015 , the bank achieved investment growth in 2016 (30\%) which was the highest in the last five years. After the year, it experienced lower investment each year of 2017 (21\%), 2018 (14\%) and 2019 (11\%) consecutively. However, the bank had the highest growth of investment profit in 2018 (34.91\%) whereas 2019 ended with an $11.39 \%$ investment profit growth rate due to unfavorable external shocks. This implies the bank was consistently able to increase the amount of investment with a lower rate whereas the bank remains inconsistent and inefficient to some extent in managing the investment.

In the bottom line, it can be said that SIBL is marching towards sustainability of a huge knowledge base as a banking institution by keeping year wise and long-term goals where they rely on meritorious and skilled human resource team to build Bangladesh a prosperous and selfsufficient "Sonar Bangla".

\section{REFERENCES}

Ahmad, A. U. F., \& Hassan, M. K. (2007). Regulation and performance of Islamic banking in Bangladesh. Thunderbird International Business Review, 49(2), 251-277. https://doi.org/10.1002/tie.20142

Ahmed, S. F., \& Malik, Q. A. (2015). Credit risk management and loan performance: Empirical investigation of micro finance banks of Pakistan. International Journal of Economics and Financial Issues, 5(2). Retrieved from https://dergipark.org.tr/en/pub/ijefi/issue/31969/352159?publisher=http-www-cag-edutr- ilhan- ozturk 
Akber, S. M., \& Dey, A. (2020). Evaluation of the Financial Performance between Traditional Private Commercial Banks and Islamic Banks in Bangladesh. International Journal of Islamic Banking and Finance Research, 4(2), 1-10. https://doi.org/ 10.46281/ijibfr.v4i2.640

Bb.org.bd. (2020). [online]. Retrieved November 25, 2020, from https://www.bb.org.bd/en/index.php

Das, S. (2012). Categorization of loans and credit risk management of Trust bank limited. Retrieved from http://hdl.handle.net/10361/1620

Hamdi, F. M., \& Zarai, M. A. (2013). Perspectives of earnings management in Islamic banking institutions. International Journal of Business and Management Invention, 2(9), 26-38. Retrieved from https://docuri.com/download/international-journal-of-business-andmanagement-invention-ijbmi_59c1e350f581710b286a9cef_pdf

Hossain, M. (2018). Credit Risk Management of Commercial Banks-a case on Bangladesh Development Bank Limited (BDBL). Retrieved from http://dspace.uiu.ac.bd/handle/52243/653

Islam, K. M., Alam, M. B., \& Hossain, M. M. (2019). Impact of Credit Risk Management on Bank Performance: Empirical Evidence from Bangladesh. South Asian Journal of Management, 26(2).

Lalon, R. M. (2015). Credit risk management (CRM) practices in commercial banks of Bangladesh: "A study on basic bank Ltd.". International Journal of Economics, Finance and Management $\quad$ Sciences, 3(2), https://doi.org/10.11648/j.ijefm.20150302.12

Mosharrafa, R. A. (2013). Credit Assessment Practice of a Commercial Bank in Bangladesh. International Journal of Economic, Finance and Management Sciences, 1 (6), 382-387. https://doi.org/10.11648/j.ijefm.20130106.25

Mtaki, F., \& Ganesh, B. (2016). Loan management and risk practices in Banks. Retrieved from http://epratrust.com/articles/upload/16.Frank\%20\%20Mtaki\%20\&\%20\%20Dr.\%20B.\%2 0Ganesh.pdf

Njeru, M., Mohhamed, S., \& Wachira, M. A. (2017). Effectiveness of credit management system on loan performance of commercial banks in Kenya. International Journal of Finance and Accounting, 2(1), 106-122. https://doi.org/10.47604/ijfa.261

Noman, A. H. M., Pervin, S., Chowdhury, M. M., \& Banna, H. (2015). The effect of credit risk on the banking profitability: A case on Bangladesh. Global journal of management and business research. Retrieved from https://www.journalofbusiness.org/index.php/GJMBR/article/view/1664 
Olabamiji, O., \& Michael, O. (2018). Credit management practices and bank performance: Evidence from First Bank. South Asian Journal of Social Studies and Economics, 1-10. https://doi.org/10.9734/sajsse/2018/v1i125772

Poudel, R. P. S. (2012). The impact of credit risk management on financial performance of commercial banks in Nepal. International Journal of arts and commerce, 1(5), 9-15. Retrieved from https://omkaw.info/01-01-42.pdf

Rosenberg, E., \& Gleit, A. (1994). Quantitative methods in credit management: a survey. Operations research,42(4), 589-613. https://doi.org/10.1287/opre.42.4.589

Sabeza, F., Shukla, J., \& Bajpai, G. (2015). Assessing Credit Risk Management Practices and Performance of Commercial Banks in Rwanda. International Journal of Social Science and Humanities Research. Kigali, 3, 323-333. Retrieved from https://www.academia.edu/29541120/Assessing_Credit_Risk_Management_Practices_n d_Performance_of_Commercial_Banks-1213_4_.

Sarker, M. A. A. (1999a). Islamic banking in Bangladesh: performance, problems, and prospects. International Journal of Islamic Financial Services, 1(3), 15-36. Retrieved from http://easymoneyhere.0fees.net/3.pdf

Sarker, A. A. (2000b). Regulation of Islamic banking in Bangladesh: role of Bangladesh bank. International journal of Islamic financial services, 2(1), 67. Retrieved from http://www.iaif.ir/images/khareji/articles/bank/2.pdf

siblbd.com. Social Islami Bank Bangladesh Limited (SIBL) [online]. Retrieved December 05, 2020, from https://www.siblbd.com/

Sufian, F., \& Habibullah, M. S. (2009). Determinants of bank profitability in a developing economy: Empirical evidence from Bangladesh. Journal of business economics and management, 10(3), 207-217. https://doi.org/10.3846/1611-1699.2009.10.207-217

Suzuki, Y., \& Uddin, S. S. (2016). Recent trends in Islamic banks' lending modes in Bangladesh: An evaluation. Journal of Islamic Accounting and Business Research. https://doi.org/10.1108/JIABR-07-2013-0026

Swartz, N. P. (2013). Risk management in Islamic banking. African Journal of Business Management, 7(37), 3799-3809. https://doi.org/10.5897/AJBM12.741

\section{Copyrights}

Copyright for this article is retained by the author(s), with first publication rights granted to the journal. This is an open-access article distributed under the terms and conditions of the Creative Commons Attribution license (http://creativecommons.org/licenses/by/4.0) 